\title{
The effect of exposure duration of self etch dentin bonding on the toxicity of human gingival fibroblast of cell culture
}

\author{
Sri Lestari \\ Department of Conservative Dentistry \\ Faculty of Dentistry, Jember University
}

Jember - Indonesia

\begin{abstract}
Self etch dentin bonding created to make light easily activate the application of composite resin on tooth surface. The monomer content has acid effect that could irritate tooth pulp. The purpose of this study was to evaluate the effect of light exposure duration of self etch dentin bonding on toxicity of human gingival fibroblast of cell culture by MTT assay. Self etch dentin bonding was used as on experimental unit and the sample was exposed by visible light curing in different duration: 10, 20, 30 seconds and immerged in artificial saliva in $\mathrm{pH} 7$ for 24 hours. $100 \mu \mathrm{l}$ artificial saliva was exposed to human gingival fibroblast of cell culture 20.000 cells/100 $\mu l$ RPMI for 24 hours. Toxicity was evaluated by MTT assay, optical density was measured using 550 nm spectrophotometer. The data was analyzed using Kruskal Wallis in 5\% degree of significance. The result showed that increasing exposure duration (10, 20, 30 seconds) of self etch dentin bonding will reduce the toxicity of human gingival fibroblast of cell culture. It is concluded that 30 seconds-exposure of self etch dentin bonding will reduce the toxicity of human gingival fibroblast of cell culture.
\end{abstract}

Key words: exposure duration, self etch dentin bonding, toxicity, MTT assay

Correspondence: Sri Lestari, c/o: Bagian Ilmu Konservasi Gigi, Fakultas Kedokteran Gigi Universitas Jember. Jln. Kalimantan No. 37 Jember 68121, Indonesia. Telp. (0331) 333536

\section{INTRODUCTION}

The use of filler with similar color of natural tooth has high esthetical value and it is increasingly applied due to the increasing knowledge and awareness in oral health. The filler material is composed of visible light composite resin. Before finally filling is performed, the application procedure is considerably complicated, requiring acid etching technique for tooth surface adhesion and bonding application. Totally etching technique is performed using phosphate acid and to remove residual acid, irrigation is done. Etching technique is applied to support the adhesion process of composite resin on tooth surface while bonding material should be previously applied. This episode would have an impact on the duration of existing fuller material on tooth surface.

The material of dentin bonding-generating VI (self etch type) is created to simplify the procedure of bonding application and it is adhesive material with one step system which would enable a dentist to perform simultaneously etching, priming and bonding. ${ }^{1}$ Self etch technique does not require acid etching phase and prolonged irrigation therefore it could be time saving for clinical application. Bonding material self etch type is containing monomer with acid $\mathrm{pH}$, polymer and adhesive resin. The application without irrigation would possibly cover the acid material and long duration contact with dentin is really vital. ${ }^{2}$ Self etch type is achieved by increasing the concentration of acid resin monomer. Water is an important additional material to ionize monomer to enable adhesive material to have optimal function, while. Etching should be performed on smear layer as well as on the dentin, consequently, hybridized smear layer and hybrid layer would be formed on dentin. One of the advantages of self etch type is not to remove smear layer during etching, priming and bonding process, but to modify, therefore, smear plug is formed to decrease hydrophilic flow through dentinal tubule. ${ }^{1}$

Residual monomer is a substance which is unreacted at the end of polymerization. ${ }^{4}$ Residual monomer and acid in dentin bonding applied on tooth tissue would immediately come into contact. They would be released into the adjacent soft tissue or pulp tissue resulting the death of cells.

Resin based restorative dental material would release the substance having biological viability. The application of most sophisticated method to detect the substance is unable adequately to detect biological property correlated with the concentration. ${ }^{5}$ Primary component which is mostly released from urethane dimethacrylate (UDMA) composite resin is monomer, then followed by small number of 1.6 Hexane dimethacrylate, chamfer Quinone. ${ }^{6}$ Resin based restorative material shows cytotoxicity effect and in-vitro change of cell function, while, High Performance Chromatography (HPLC) is incapable to detect clearly the number of released substance. ${ }^{5}$ When the polymerization process is completed, the component existed in tooth resin would be immediately eluated into the environment resulting metabolic change in various cells. $^{7}$

Exposure duration is one of the factors affecting polymerization of resin monomer originating from bonding material and composite resin. Effective exposure 
duration for composite resin is 20 to 60 seconds with $2 \mathrm{~mm}$ restoration thickness. ${ }^{8}$ The 10 second of exposured duration is recommended by the manufacture for self etch dentin bonding. The increase of exposured duration would cause more adequate polymerization of adhesive resin composed of bonding material self etch type resulting low residual monomer.

Prolonged exposure duration whether it would terminate the process of acid etching in tooth hard tissue contacting to bonding material is still unknown. The impact on physical and chemical property as well as on adjacent soft tissue occurring in the process of acid etching without irrigation followed by polymerization is also unknown. The impact on soft tissue in-vitro test could be identified by toxicity occurring in human gingival fibroblast of primary culture cell. The use of human gingival fibroblast of primary culture cell because it has been considered closed to natural condition compared to animal fibroblast it culture cell or line cell and it has different sensitivity.

Toxicity test using MTT assay is a method which is considered sensitive and easy to be done to detect living cell compared to other methods. MTT assay is based on the capability of living cell to reduce MTT salt. The principle is to break down ring of MTT tetrazolium [3-(4.5 dimethilthiazol-z-yl)-2.5-diphenyl tetrazolium bromide)] through dehydrogenase in active mitochondria, producing unsoluble blue formazan. ${ }^{9}$ Formazan product can be counted by dissolving and measuring optical density of solution outcome. ${ }^{8}$ Blue color reaction is used as an indicator of living cell measured as MTT product using spectrophotometer with $570 \mathrm{~nm}$ wave length., 10

Based on the above explanation, a study is necessarily conducted on the effect of exposure duration of bonding material self etch type in toxicity of human gingival fibroblast of primary culture cell using MTT assay. The advantage of the outcome is to understand the impact of exposure duration and toxicity on human gingival fibroblast.

\section{MATERIALS AND METHODS}

The study was performed by experimental laboratory. Method and self etch type as the sample. The artificial saliva was composed of $36 \mathrm{gr} \mathrm{NaCl}, 1.69 \mathrm{gr} \mathrm{KCl}, 0.95$ $\mathrm{CaCl}_{2}, 0.85 \mathrm{gr} \mathrm{NaHCO}_{3}$ and $400 \mathrm{cc}$ destilled water. The devices applied were light curing (latex), micropipette, flask, conical, petridish, syringe, 96 well micro plate, laminar flow, $\mathrm{CO}_{2}$ incubator, spectrophotometer, sheaher, centrifuge, and counter. The sample was classified into 3 groups according to exposure duration: 10, 20, 30 seconds, each group was consist of 7 samples.

Material of self etch type dentin bonding was mixed equally $1: 1$, homogenously stirred using brush. $10 \mu \mathrm{l}$ mixture was taken by micro point and poured sterile aluminium foil, followed by curing in individual group for $10,20,30$ seconds and soaked in tube containing $1500 \mu \mathrm{l}$ artificial saliva for 24 hours, the mixture was removed after the period was over. The next process, the artificial saliva which was used to soak the self etch type dentin bonding (eluate) would be applied as the sample of the study. $100 \mu \mathrm{l}$ of each controlled group was taken for toxicity test.

The preparation process of human gingival fibroblast of primary culture was performed by obtaining gingival tissue taken from extracted gingival of healthy tooth. Next, the gingival tissue was washed using Povidon Iodine, and irrigated by phosphate buffer saune (PBS). Gingival tissue was repeatedly washed (3 times) by PBS composed of Penicillin and Streptomycin in petridish and cut into pieces using sterile scissors. Next, it was placed in another petridish filled by RPMI culture media added by fungi zone or gentamycin. The petridish was covered and shaken to make the gingival tissue equally spread in petridish. The incubation was done for 3 days in $5 \% \mathrm{CO}_{2}$ incubator at $37^{\circ} \mathrm{C}$, the process was done in sterile environment of laminar flow. Culture media was changed once in 3 days until the cell growth would reach $50 \%$ of petridish surface or confluent in which the subculture would be possibly conducted.

Toxicity test was performed using 96 hole microplate in which in every hole would accommodate 20.000 human gingival fibroblast of cell culture and $10100 \mu \mathrm{l}$ RPMI. In negative controlled group consisted of cell + RPMI media, while, cell + RPMI media + artificial saliva in positive controlled group. Controlled group included the sample consisted of $100 \mu$ artificial saliva which had been exposed by eluate of self etch type dentin bonding in different exposure duration (10, 20, 30 seconds) in every hole. Microplate was incubated for 24 hours (or 20 hours) in $5 \% \mathrm{CO}_{2}$ incubator then removed out and added by $5 \mathrm{mg} / \mathrm{ml} \mathrm{MTT}$ and $100 \mu \mathrm{PBS}$ in every hole. The incubation was continued for 4 to 5 hours, the supernatant was disposed, meanwhile, $200 \mu$ dimethyl sulfoxide (DMSO) was dropped in every hole, waited for 5 minutes, sheaher was done in $30 \mathrm{rpm}$ for 30 minutes the supernatant was removed then it was washed twice using $100 \mu \mathrm{PBS}$. The next, microplate was inserted into spectrophotometer in 550 $\mathrm{nm}$ wave length and color absorbance could be identified (formazan optical density = optical density).

\section{RESULT}

The mean of optical density, the percentage of living cell and primary culture toxicity of human gingival fibroblast cell exposed by eluate of self etch dentin bonding type in artificial saliva could be shown in Table 1.

Low toxicity was shown by high optical density, on the contrary high toxicity was shown by low optical density. The higher the number of living cell, the higher the amount of color absorbance would occur (high OD) showing low toxicity. Toxicity scoring was identified by OD value in controlled group cell + media was $100 \%$ (estimated toxicity value $=0$ ) cell toxicity was consecutively graded 
Table 1. The mean of optical density, the percentage of living cell and the toxicity of human gingival fibroblast of cell culture exposed by eluate of self etch type dentin bonding

\begin{tabular}{|c|c|c|c|c|c|c|c|c|c|}
\hline & \multicolumn{3}{|c|}{10 seconds } & \multicolumn{3}{|c|}{20 seconds } & \multicolumn{3}{|c|}{30 seconds } \\
\hline & OD & $\mathrm{LC}$ & DC & OD & $\mathrm{LC}$ & DC & OD & $\mathrm{LC}$ & DC \\
\hline $\begin{array}{l}\text { Cell + media } \\
(\text { controlled })\end{array}$ & 0.772 & $100 \%$ & $0 \%$ & 0.772 & $100 \%$ & $0 \%$ & 0.772 & $100 \%$ & $0 \%$ \\
\hline $\begin{array}{l}\text { Cell + media + artificial } \\
\text { saliva (controlled) }\end{array}$ & 0.767 & $99.3 \%$ & $0.76 \%$ & 0.767 & $99.3 \%$ & $0.76 \%$ & 0.767 & $99.3 \%$ & $0.76 \%$ \\
\hline $\begin{array}{l}\text { Eluate of bonding dentin } \\
\text { in } 100 \mu \text { artificial saliva }\end{array}$ & 0.206 & $26.7 \%$ & $73.3 \%$ & 0.437 & $56.6 \%$ & $43.4 \%$ & 0.465 & $60.2 \%$ & $39.8 \%$ \\
\hline
\end{tabular}

Note: $\mathrm{OD}=$ optical density, $\mathrm{LC}=$ Living cell, $\mathrm{DO}=$ Death cell $>50 \%$

according to exposure duration: 10, 20, 30 seconds. Prior to statistical analysis. Homogeneity test was done using Levene test showed value of significance $0.001(\mathrm{p}<0.005)$, the meaning is in homogeneous data. The next followed by non parametric test using Kruskal Wallis. The result could be shown on table 2 .

Table 2. Kruskal Wallis statistical test analysing toxicity of human gingival fibroblast of cell culture exposed eluate of self etch dentin bonding

\begin{tabular}{lc}
\hline & Exposure duration \\
\hline Chi square & 8.440 \\
Df & 6 \\
A symp sig & 208 \\
\hline
\end{tabular}

The result of Kruskal Wallis test showed no significant difference was found in the group exposed by eluate of bonding dentin self etch in exposure duration 10, 20, 30 seconds ( $p>0.001)$ indicating that toxicity of human gingival fibroblast of cell culture was not affected by the increase of exposure duration of self etch type dentin bonding.

\section{DISCUSSION}

The result of the study showed there was no significant difference in toxicity among the groups with exposure in different duration. The highest toxicity was found in bonding dentine self etch type for 10 second exposure due to unpolymerized monomer which was much higher comparing to 20 seconds and 30 seconds exposure. Lack exposure decreased energy which functioned to activate polymerization process therefore the degree of polymerization would also decrease $e^{4}$ and the decrease of light energy would also simultaneously contribute the decrease of photon number which was useful to activate free radical formation. ${ }^{12}$ Consequently the decrease of free radical would make the process of polymerization less maximal resulting in the increase of residual monomer. Residual monomer would be instantly released into fluid environment producing the response on the contact site of dentin bonding. ${ }^{7}$ The finding is also supported by the idea that cytotoxity occurs due to the release of unpolymerizes main component from the material on air resistant layer.

Inadequate polymerization process might make high concentration of residual monomer. ${ }^{13}$ The release of residual monomer would be more and higher in bonding dentin self etch type which has high concentration residual monomer, because bonding dentin self etch type with low exposure duration possibly will have high residual monomer therefore the release would come into contact with the adjacent fluid tissue is high resulting higher value of toxicity compared to 20,30 second-exposure duration. In this case, it is in accordance with the previous study stated that inadequate polymerized monomer would release $50 \%$ after 3 hours being soaked in oral fluid and $85-100 \%$ after 24 hours. ${ }^{14}$ In this study, the existing residual monomer could be released into artificial saliva affecting soft tissue and as a matter of fact the residual monomer was toxic to human gingival fibroblast. It was revealed in bonding dentin for 10 secondexposure that OD 0.206 , living cell $26.7 \%$, toxicity $73.3 \%$ (CD $>50 \%$ ), it was evidently toxic. The toxicity of residual monomer was also similar to the previous study suggested that dental material would be toxic in the condition of CD $>50 \% .{ }^{15}$ The analysis using Kruskal Wallis showed no significant difference suggesting the cytotoxicity was most possible due to the acid content in bonding dentin as well as residual monomer resulted from incomplete polymerization process. ${ }^{1,16}$ The occurrence of many dead cells because of acid monomer $(\mathrm{pH}<1)$ content in bonding dentin self etch type. ${ }^{1}$ The elevation of cell membrane permeability was also contributed by the monomer, as a result, internal plasma membrane was exposed by the acid material, therefore, cell inflammation would eventually exhibit the synthesis process and dead cell would occur. Low $\mathrm{pH}$ might also cause protein denaturation that was the damage of covalent intra molecular binding disulfide and ionic binding, hydrophobic and hydrogen binding. ${ }^{16}$

Another reason suggested that bonding dentin self etch type was consisted of HEMA which was used to increase the strength of bonding and dentin with 130.14 molecule weight could be completely soluble in water. High concentration supported by HEMA rapid release in self etch dentin 
bonding. ${ }^{17}$ In addition, the cause of toxicity was the activity of material which was not neutralized by calcium ion of the teeth as it was clinically applied in-vivo study. This would differ between the application on tooth with in-vitro study without application on tooth tissue.

Performing in vitro toxicity test on cell culture could be the evidence of initial biocompatibility of dental material. In this study, primary culture of human gingival fibroblast cell was applied in order to achieve closely similar to natural clinical condition. Because human gingival fibroblast cell is the most important cell and the biggest component of pulp and periodontal ligament, in this study primary culture of gingival tissue was applied. The strength of primary culture of human gingival fibroblast cell is having sensitive response compared to cell line culture. The weakness is primary culture having short life span and difficult to do repeated subculture therefore it requires procedure of new culture process for application.

Based on the result of the study, it could be concluded that 10,20, 30 seconds light exposure of dentin bonding self etch type on human gingival fibroblast cell reduces toxicity.

\section{REFERENCES}

1. Wei SH, Tay FR. Xeno III and self etch bonding. Clinical Suplement 2003; Update (Mei-Agustus, 14): 1-5.

2. Van Meerbek B. Adhesion to enamel and dentin current status and future challenges. Operative Dentistry 2003; 215-35.

3. Pashley DH, Tay FR. Aggressiveness of contemporary self etching adhesives part II: Etching effects on unground enamel. Dental Material 2001; 17:430-44.
4. Siswomihardjo W. Poliester EBP 2421 sebagai alternatif bahan basis gigi tiruan. Disertasi. Surabaya: Pascasarjana Universitas Airlangga; 1999. p. 80-5.

5. Wataha JC, Rueggerberg FA, Lapp CA, Lewis JB. In vitro cytotoxicity of resin containing restorative materials after aging in artificial saliva. Clinic Oral Invest 1999; 3:144-9.

6. Mohsen NM, Craig RG, Hanks CT. Cytotoxity of urethane dimethacrylate composites before and after aging and leaching. J Biomed Mater Res 1998; 39(2):252-60.

7. Lefebvre CA, Knorenschild KI, Schuster GS. Cytotoxicity of evaluates from light-polymerized based resin. J Prosth Dent 1994; 72:644-50.

8. Craig RG, Powers JM. Restorative dental materials. $11^{\text {th }}$ ed. St. Louis: CV Mosby Co; 2002. p. 136-7.

9. Kasugai S, Hasegawa N, Ogura H. Application of the MTT colorimetric assay to measure cytotoxic effects of phenolic compounds on established rat dental pulp cells. J Dent Res 1991; 70:27-30

10. Fazwishni S, Hadijono BS. Uji sitotoksisitas dengan esei MTT. J Ked Gigi Universitas Indonesia 2000; 7:28-32.

11. Kawaguchi M, Takahashi Y, Fukushima T, Habu T. Effect of light exposure duration on the amount of leachable monomers from lightactivated reline materials. J Prosth Dent 1996; 75:183-7.

12 Annusavice JK. Phillip's science of dental materials. $10^{\text {th }}$ ed. Philadelphia, London, Toronto, Montreal, Sydney, Tokyo: WB Saunder's Co; 1996. p. 69-298.

13. Pearson GJ, Longman CM. Water sorption and solubility of resinbased material following inadequate polymerization by a visible- light curing system. J Oral Rehab 1989; 16:57-61.

14. Hanks CT, Strawn SE, Wataha JC, Craig RG. Cytotoxic effects of resin components on cultured mammalian fibroblast. J Dent Rest 1991; 70(11):1450-5.

15. Telli C, Serper A, Dogen AL, Guc D. Evaluation of the cytotoxity of calcium phosphate root canal sealers by MTT assay. Journal Endodontics. 1999; 25:811-3.

16. Erawati W, Latief M, Theresia IBS. Uji Sitotoksisitas ekstrak air asam jawa 5\% terhadap cell line BHK 21. Indonesian Journal of Dentistry 2007; 14(1):18-21.

17. Vajrabhaya L, Pasasuk A, Harnirattisai C. Cytotoxicity evaluation of single component dentin bonding agents. Operative Dentistry 2003; $20: 442-4$. 